\title{
Foundations of Torey Hayden's Relationship-Driven Classroom Practice with Troubled Children
}

\author{
Mike Marlowe $^{1}$ \\ Appalachian State University, Boone, North Carolina, USA
}

\begin{abstract}
This paper discusses the relationship-driven classroom practice of Torey Hayden, a teacher of children with emotional and behavioral difficulties, and author of eight books chronicling her day-to-day work in special education and child psychology. Seven philosophical principles which underpin and inform all action taken in her relationship-driven classroom model are delineated: 1) relationships are a process, not a goal; 2) there is a difference between a person and the person's actions; 3) no one chooses to be unhappy; 4) misbehavior is a teaching opportunity; 5) everyone can change; 6) personal change is very difficult; and 7) the world is complex. A consilience of evidence supporting the use of a relationshipdriven methodology with troubled children is presented. Final thoughts on Hayden's relationship-driven classroom are offered.
\end{abstract}

Keywords: Torey Hayden; special education; child psychology

Torey Hayden, a teacher of children with emotional and behavioral disorders, has authored eight books which offer readers a real world look at the everyday problems, successes, and struggles of teaching and counseling children whose lives are marked by abuse and trauma, anger and defeat. Hayden's first book was One Child (1980), the story of Sheila, a silent troubled girl, who had tied a three year old boy to a tree and critically burned him. One Child was followed by Somebody Else's Kids (1982), Murphy's Boy (1983), Just Another Kid (1986), Ghost Girl (1992), The Tiger's Child (1995), the sequel to One Child, Beautiful Child (2002), and Twilight Children (2006).

Hayden's teacher stories are remarkable for their emphasis on relationships (Marlowe, 1999; 2006; 2011). They stress the interpersonal dynamics and emotional connections involved in working with troubled children. Her stories give special voice to the power of relationship skills, intuition, and the social milieu in changing behavior, and they emphasize the synergistic power of relationships between a teacher and her students. In her prologue to The Tiger's Child, Hayden noted this reciprocal effect in her relationship with Sheila: "This little girl had a profound effect on me. Her courage, her resilience, and her inadvertent ability to express that great gaping need to be loved that we all feel - in short, her humanness brought me into contact with my own." (Hayden, 1995, p. 8)

\footnotetext{
${ }^{1}$ Department of Reading Education and Special Education, Appalachian State University, Boone, North Carolina 28607, USA. Email: marlowemj@appstate.edu.
} 


\section{The Relationship-Driven Classroom}

To Hayden, there is no single framework upon which we can hang all interpretations of human behavior. Any given theory, to her way of thinking, simply provides one interpretation and, like climbing the proverbial mountain, there are many other paths one could take

While Hayden is open about the fact that she follows no specific model, I have distilled from her stories an approach to educating troubled children which I refer to as relationship-driven (Marlowe, 2011). The crucial foundations of a relationship-driven classroom are the individual relationships between the teacher and the child and those among the children and the group or unit relationship. What sets the relationship-driven methodology apart from other methodologies is its active use of interpersonal relationships as a medium of change.

I observed that Hayden's first order of business is to establish a relationship with the child. Initiating and sustaining a relationship with a child is the only context in which other interventions can succeed.

The cornerstone of this relationship-driven approach is commitment. It is the unequivocal commitment of one individual to another that evokes positive change. Troubled children have to have this type of relationship if they are going to move forward. They need the esteem that comes only from knowing others care about you, others value you sufficiently to commit to you. They need to know that while significant others may have been unable to provide this type of commitment, it does not mean they are unworthy of it. As Urie Bronfenbrenner (2005) proclaimed, every child needs at least one special adult who is irrationally crazy about him or her, for only then can they develop to full potential.

In One Child, Hayden changes Sheila's behavior by forming a relationship between them. Sheila changes because it mattered to Hayden that she change. Although Sheila was able to internalize her changes eventually, in the beginning the change happened because of the relationship between the two of them, and because Hayden made it apparent that it was important to her that Sheila change. The desire to be liked is writ large in human relationships. 


\section{Marlowe}

\section{Underlying Principles of a Relationship Driven Classroom}

There are seven philosophical principles that underpin relationships as a means of change (Hayden \& Marlowe, in press). These principles evolved from Hayden's dayto-day interactions with her children more than they were applied.

\section{Relationships are a process, not a goal}

There are two different approaches whether it is working with troubled children or whether it is towards life in general - goal orientated or process orientated Both orientations are a normal part of human behavior. In goal orientation you do what you do for the ultimate outcome. With a troubled child, for example, you work with him because you have expectations of making him better and more capable of living a fulfilling life. You have expectations of an outcome from the time you undertake what you are doing. Fulfillment comes when you reach the goal.

In process orientation you do what you do for the process of doing it. With a troubled child you don't have any expectations of what's going to happen because you are not looking at the future. You work with the child because you enjoy the act of being with the child. This means you focus on the process, the doing of something, rather than the outcome. Consequences or outcome of the experience may reinforce the behavior but they are not at the heart of this orientation. Fulfilment comes instead from awareness and appreciation of having the experience while it is happening.

Relationships are, by their very nature, process oriented. They are ongoing and now. The relationship-driven model is present oriented because relationships only exist in the present. Thus in order to use relationships as a way of changing behavior, one must be oriented to the present process as opposed to towards a future goal. In other words, the relationship the teacher has with the child now is used to change behavior as opposed to its being a reward or an outcome of the change. The teacher is working with the environment, modifying what is happening "right now" by means of relationship skills, intuition and social milieu, all of which exist only in the present.

Staying in the present, staying in the process helps one accept the child. People who focus on goals tend to be judgmental. They are judging the child against the final product, and if you haven't reached your goal you are seen as wanting. Acceptance is the ground work of trust. We tend to form relationships with the people we feel accept 
us. We need to communicate to the child that who the child is "right now" is sufficient for me to want to form a relationship.

Hayden has been able to avoid 'burn out' because she is a process-oriented person as opposed to a goal oriented person. In her experience it is the people who need to succeed - to see success at the end of what they are doing - who burn out. These are goal oriented people. They are doing what they are doing for the outcome, and because the outcome with troubled children is often negligible, they lose their enthusiasm. Hayden works with children because she thoroughly enjoys the process itself. She loves the act of being with the children. While she is open to the fact that improvement for her children is desirable, this is not what guides her work. Her pay-off, her fulfilment in working with children comes during the time spent together, during the interactions, during the moment itself (Hayden, February 28, 2001).

\section{There is a difference between the person and the person's actions}

Hayden is unequivocally on the child's side. This doesn't mean accepting everything the child does, but it means making clear that the child him/herself is acceptable. The difference between the person and the person's action is another way of saying it.

Understanding the difference between the person and the person's actions is also at the heart of developing a tolerant and nonjudgmental attitude toward children's capacity to change. If a child's actions were as unchangeable as his/her identity, then there would be little scope for his/her learning new or more adaptive behaviors because "he/she'll always do that," or "he/she won't change." Understanding that a person isn't his/her actions, regardless of the number of times he/she has engaged in a certain action, allows us recognize he/she has the capacity for different actions.

It is imperative we actively maintain this optimism regarding the possibility of change: self-esteem can be rebuilt, motivation can be re-instilled, new lives can take form as long as there is hope this is possible. As teachers there's not much point being in the classroom if we don't genuinely believe children can change. Likewise, it is important to instil this hopefulness in the children. Hope builds spiritual strength and self-efficacy giving the young person the courage to change. 


\section{Marlowe}

No one chooses to be unhappy

Unhappiness makes one feel dismal as attested to when Hayden asked her students to write about something that made them unhappy One girl wrote, "What makes me unhappy is going to bed and it will be so cold and so dark. I don't like to be there. I'm scared and I cry." Another child wrote, "Sometimes I wish I was dead. I want to kill myself. I get so sad. Nobody cares. I almost want to kill myself. I wish I knew what to do. Nobody likes me and I don't much either. I just wish I know what to do." And another child, "Once I got so unhappy I cried to God. I put a bag on my head and tied a string around it and I sat in my closet on the closet floor. It didn't work. I'm still alive" (Hayden \& Marlowe, 2005).

Hayden believes we all want to be happy. Everything we do, no matter how odd or misguided, is done because we think consciously or unconsciously that it will lead to our feeling happier. This is simply another way of saying "Everyone is doing the best they can." Children engaging in difficult or destructive behaviour do so in erroneous belief that this will relieve their unhappiness. They are not actively trying to be unhappy. Instead, they are actively trying to be happy but going about it in an unproductive way, because - for whatever reason - they are simply not able to do differently at this point in time. A misbehaving child isn't wilfully choosing to be unhappy. He/she genuinely hasn't come up with a more effective way of being happy.

Understanding this concept is important to relationship forming because it helps us realize that however irksome, stupid, or incomprehensible a child's behaviour seems to be, they won't be doing it just to irritate us. They will be behaving this way because, for whatever reason, they simply don't know how to do differently.

Once you arrive at a place of understanding that children do not choose to be unhappy, you can then surmise that if they continue doing something that repeatedly makes them unhappy, it is because - for whatever reason - they are simply unable to do differently at this point in time. So that is when we recognize it is no longer solely their responsibility but ours as well to sort this problem out, because if a load is too heavy for a child to carry, others standing around pointing fingers at him will never get it shifted. Instead, we can help. We can teach him how to shift it. We can encourage him. We can share the burden until he is strong enough. 
If everyone wants happiness and no one wants unhappiness. yet there is misbehavior that results in unhappiness, then Hayden assumes the person does not know how to do differently. If he/she did, he/she would be doing it, because unhappiness is generally displeasing. If, on the other hand, someone doesn't know how to do differently, then the appropriate response from those who do is to teach him or her how.

Most children in programs for emotional and behavioural disorders will have considerable familiarity with dysfunctional adults and dysfunctional relationships. In contrast, they will have little experience of functional adults relating appropriately. Hayden posits it is thus both unrealistic and unreasonable to expect children to disengage from difficult cycles of behavior on their own without first gaining experience of the functional behaviors they need to emulate. In a relationship-driven methodology, functional behavior is taught actively via the teacher-child relationship in order to give children experience of the appropriate behaviors they are expected to use. Some aspects of appropriate behavior are taught by the teacher through active modelling and others are taught to the child directly, such as how a functional person manages his/her emotions, how a functional person relates appropriately to others, and how a functional person handles negative situations.

Hayden cautioned an audience of teachers to always remember you are a teacher (Hayden and Marlowe 2005). Tackle misbehaviour from the perspective of a teacher. That means you need to teach appropriate behaviour. Don't approach behaviour from the perspective that it needs to be punished. Punishment can cause students to resent their teachers and even rebel against them. In the relationship-driven classroom the first line of intervention is not punishment but teaching appropriate behaviour.

To elaborate, an example of a child who misbehaves because he/she does not know how to behave differently was One Child's six-year-old Sheila whose life was a pornographic tale. Sheila was often very rude with the other children. She had never been taught how to be kind or polite or considerate of others. When someone got the place in line she had chosen, she socked that person hard enough to win it back. If another child had a toy she wanted, she grabbed it, wrestled it out of the child's hand, and scuttled off to safety with it to hiss angrily at anyone who tried to take it away. The 


\section{Marlowe}

natural consequence of this was that other children didn't like her very well and didn't want to play with her.

To punish her for not being polite, for not obeying rules would have been a bad decision on the part of Hayden. It was more efficient to regard Sheila's behaviour as a teaching opportunity. She didn't actually know how to be polite (didn't know how to behave differently.) "Please" and "thank you" were not used regularly in her home environment and she had not been actively taught social skills by the adults around her. Role play and direct teaching were used ("When you want something, you say, "Please may I have it," and if they give it to you, you say, "Thank you.") and when she forgot, she was reminded. Natural consequences in the form of the other children responding more positively to her efforts to be polite reinforced this teaching.

So discipline in a relationship-driven classroom can be summed up as: never pass up an opportunity to teach. Being a teacher overarches every other aspect of what you do. You are not a prison warden. You are a teacher. This means you want to approach every situation in the classroom with a mind open to teaching opportunities, because this is what you are there to do.

\section{Everyone can change}

Hayden believes that everyone regardless of who they are and what they have done, can change. This belief is the foundation upon which all the rest of the relationship-driven model is built.

Everybody can change is just a practical attitude. Pollyanna says, "Everyone will change." This statement is just as black-and-white as "He'll never change." What Hayden wants to cultivate is the ability to stay positive about the possibility of change, and the recognition that we are not omniscient. It's easy to fall into using black-andwhite terms like "always" or "never" in regards to difficult behavior, but in doing so we are implying that the children and situations we are dealing with are fixed, and discreet, and therefore entirely predictable, when they are, in fact, constantly changing and connected to and affected by an infinite number of other things that we have no knowledge of, insight into, or control over.

To claim someone is unable to change is to take the $100 \%$ nature stance that says we are little different from flatworms or amoeba - just a product of our circumstances and nothing we can do to change that. To state that a child "is bad through and through 
and can never change" is simply an excuse for excluding someone or for not getting involved and avoiding taking any responsibility for the problem yourself.

Hayden believes because we may not be able to see how change will take place doesn't mean there is no chance for change. We need to promote personal change as doable, and in the process, distinguish in our own minds the difference between "I can't do any more to help this child," and "No one can can help this child."

\section{Personal change is very difficult}

In Hayden's experience changing ingrained personal behavior is very hard to do. There are many reasons for this: genetic make-up, environmental circumstances, motivation, and consequences all factor in. As a result, it is normal for the individual who is trying to change to make many approximations before managing the right behaviour. It is also normal to slip up or fail many times before eventually achieving the behavior.

Understanding this is important to tolerance and acceptance of others because it is normal human nature to want things quickly whereas in the real world it is normal to backslide, for there to slips, misses and even total failures. A tolerant teacher understands that this does not mean that change is not taking place or that change is impossible. It simply means the child hasn't got there yet.

It is normal for the increments of change to be very, very small and the more entrenched the behavior, the smaller they usually have to be for success to be maintained. Because of this, it is necessary and, indeed, crucial to reward approximations of the desired behavior as one goes along. It is also important for both teacher and child to be aware from the onset that it is entirely normal to have to make such small steps and that the person making the change should be encouraged to be positive about any movement in the right direction, however minute the increments.

Change can be slow, subtle, and difficult and very often happens in a manner much different to what we had planned or envisioned, so it is important children be aware of this and be aware this is normal. We want to help children shift away from the goal oriented judgment perspective that "I tried. I failed. I can't do it. I give up," to the process-oriented "I tried. It didn't happen this time. I'll try again." 
The world is complex

Hayden has pointed out many places that black-and-white thinking - the tendency to perceive things as all-or-nothing and thus able to be put into discernible, discreet and permanent categories - seems to be a hard-wired trait for humans. We categorize and generalize by nature.

From the perspective of a relationship-driven approach, there are three important reasons for avoiding black-and-white thinking. One, almost all behaviors are on a spectrum and not at the two (black or white) extremes. For example, we are virtually never entirely happy or entirely sad. Happy is one end of the spectrum, sad is at the opposite end and we normally tend to fall somewhere in between. Recognizing the spectrum nature of behavior makes it much easier to accept approximations of appropriate behavior and to see positive movement towards the wanted behavior because we can see what is being done is further up the spectrum than the previous behavior. In contrast, black-and-white thinking allows us only two outcomes: success or failure.

Two, black-and-white thinking tends to ignore time and the fact that all things change over time. We are not at all static creatures. We are never really the same twice. Recognizing this continual process of change allows us to recognize the potential for things to be different than they are right now. In contrast, black-and-white thinking assumes permanence and looks for opportunities to reinforce that. The blackand-white thinker looks only for evidence that reinforces categorization and ignores evidence of change. Once a bully, always a bully, for example.

And three, black-and-white rules have the potential for creating power struggles. Difficult, defiant children often react to black-and-white rules rather as if the teacher had drawn the proverbial line in the sand and said, "Don't cross this." The child just has to break the rule to show he can. This puts the teacher into the difficult position of either having to escalate to confrontation or risk losing either authority or consistency by ignoring the rule breaker. This is an undesirable situation because the teacher is being forced to react to the student rather than respond, and this is never a position of strength. So it works better if the rules are flexible enough to allow for face saving behaviour and reasonable amounts of testing behaviour to be ignored, when this is situationally appropriate. 
In the One Child classroom Hayden kept her rules open-ended. She basically only had two rules. The first one being "Do your best." Most children do have a sense of when they are trying hard - and yet it allows both the teacher and the child some wiggle room in interpreting and applying the rule. If you have a child who comes in very tired from having a very horrible night at home with his family, doing his best that day may be different from doing his best another day. Open-ended rules allow you to accommodate more easily. The second rule, "You are not allowed to hurt people, animals or things that belong to others or are for everyone to use," is more specific, but it still allows for flexible interpretations in instances of accidental behaviour and in terms of what constitutes "things for everyone to use."

So it is important when working with a relationship-based methodology that one have a clear understanding that the world is complex, that we can't reduce it to clearcut, comprehensible certainties. This kind of open-ended acceptance is one of the most crucial attributes for success in the dynamic realm of relationships.

\section{The Test for Truth}

The gold standard for truth is that an idea from one field fits with ideas drawn from other realms of experience (Brendtro, Mitchell, \& McCall, 2009). This is called consilience by philosophers of science (Wilson, 1998). Consilience links findings from separate fields to discover simpler universal principles. Consilience requires that truth be tested against the multiple perspectives of science, experience, and universal human values.

Hayden's relationship-driven classroom approach to teaching troubled youth meets the test of consilience. It is supported by knowledge from (1) biological science, (2) social science, (3) practice expertise, (4) the voices of youth and their families, and (5) universal values of respect and human dignity.

To begin, biological science reveals that the brains of children have inbuilt attachment programs which strongly motivate them to seek out positive bonds with caring adults (Cozolino, 2006). The need for belonging permeates all of our relationships; it is designed into our DNA (Salavitz \& Perry, 2010).

Two, social science research in both teaching and therapy shows the power of interpersonal relationships. Teachers of children with emotional and behavioral disorders with varied teaching styles can be successful if they develop positive 


\section{Marlowe}

relationships with their students (Morse, 2008). Likewise, a common element within all forms of effective psychotherapy and counseling is a respectful, valuing, and empathetic bond between therapist and client (Hubble, Duncan, \& Miller, 1999). Psychiatrists and psychologists call such a relationship between the therapist and client the therapeutic alliance. A similar bond - a pedagogical alliance - between teacher and student is similarly powerful when teaching students with emotional and behavioral disorders (Danforth \& Smith, 2005).

Three, practice expertise from the successful experiences and the collective wisdom of youth care work pioneers demonstrates the power of human relationships. The hallmark action research of Fritz Redl and David Wineman and Nicholas Hobbs and William Morse, early leaders in the education of children with emotional disturbances, shows that real behavior change is facilitated by relationships. Nicholas Long (2008), co-author of six editions of Conflict in the Classroom with Morse states that "if we are not successful in developing interpersonal bonds with youth, then all subsequent treatment and pedagogical techniques are mechanical. It is like racing a car engine without any oil. It is not going very far before it heats up and shuts down" (p. $57)$.

Four, experience includes not only practice expertise but also the often ignored first-hand knowledge from youth and their families. Werner and Smith (1989) studied Hawaiian children with multiple risk factors (poverty, strained parental relationships, and poor role models) for 40 years. They found that one out of three of these children developed into competent adults. They then studied the children who were able to succeed despite living with much stress and adversity and identified factors that were present in these successful children; these factors form the basis of resilience. Werner and Smith found, among other things, that these children often credited a favorite teacher who went beyond academics and became a mentor, confidant, and positive role model for personal identification. Likewise, a national survey of 12,118 adolescents by Resnick et al. (1997), titled "Protecting Adolescents from Harm," found having an adult who was supportive to them was the strongest protective factor. The adult was someone the youth could count on for understanding, advice, and support. Teachers were among those adults mentioned most frequently as the source of this support. Families of troubled youngsters also consistently report that what is significant about programs was that workers made them feel like they were important, like they cared (Garfat, 2010). 
And five, values of human dignity motivate us to create caring environments where all young persons are treated with respect (Seita, Mitchell, \& Tobin, 1996). Humans are innately disposed to treat others the way they want to be treated. This is the golden rule which is universal across all major religions.

\section{Final Thoughts on Hayden's Relationship-Driven Classroom Practice}

In setting up a relationship-driven classroom Hayden relies "fairly heavily on personal charisma" (Hayden, 1988, p. 221). Her intensely up close and personal approach tended to be effective with children, and yet it could be very hard if the school year end came before the child was ready.

Hayden has developed a philosophy of attachment and loss in forming relationships which threads through her books. For her forming relationships is central to teaching, but it inevitably implies eventual loss, just the way birth inevitably contains within it the guarantee of eventual death. One of her favorite quotes is: "A ship in the harbor is safe, but that's not what ships were built for." In other words, the only certain way to stay safe from loss is never having attachment, but research in psychology and sociobiology shows that we are a social species and are primed biologically to have relationships from birth. That Hayden formed attachments which she knew ultimately would end simply meant she was able to keep an objective eye on what was going on in her teacher-student relationships - I'm a teacher; my ending comes in June - not that she was any better at loss than her students or that it hurt her any less. Part of what she teaches in forming an attachment, is how to cope with loss, and loss comes to all of us.

Hayden's goal in forming relationships with her children as stated various times through her books is to help more than she hurts. She states that's all any of us can aim for, as the perfect person or perfect relationship does not exist. She remains committed to the idea that we all do need to know in a very real way that we matter to someone, someplace, even if we cannot be together. "And real love, for whatever time it lasts, is never wasted" (Hayden, August 31, 2001).

\section{References}

Brendtro, L.K., Mitchell, M.L, \& McCall, H.J. (2009). Deep brain learning: Pathways to potential with challenging youth. Albion, MI: Starr Commonwealth. 


\section{Marlowe}

Bronfenbrenner, U. (Ed.). (2005). Making human beings human: Bioecological perspectives on human development. Thousand Oaks, CA: Sage Publications.

Cozolino, L. (2006). The neuroscience of human relationships: Attachment and the developing social brain. New York: W.W. Norton and Company.

Danforth, S., \& Smith, T.J. (2005). Engaging troubling students: A constructivist approach. Thousand Oaks, CA: Corwin Press.

Garfat, T. (2010). The truth in their experience. The evidence from youth and families. Reclaiming Children and Youth, 19, 55-57.

Hayden, T.L. (1980). One child. New York: Avon Press.

Hayden, T.L. (1982). Somebody else's kids. New York: Avon Press.

Hayden, T.L. (1983). Murphy's boy. New York: Avon Press.

Hayden, T.L. (1986). Just another kid. New York: Avon Press.

Hayden, T.L. (1992). Ghost girl. New York: Avon Press.

Hayden, T.L. (1995). The tiger's child. New York: Avon Press.

Hayden, T.L. (2001, February 28). Goal or process oriented? Message retrieved from

http://www.torey-hayden.com/Message board/Our archives/About the books/Somebody else's kids.

Hayden, T.L. (2001, August 31). Attachment and loss. Message retrieved from

http://www.torey-hayden.com/Message board/Our archives/Psychology and psychiatry issues.

Hayden, T.L. (2002). Beautiful child. New York: Avon Press.

Hayden, T.L. (2006). Twilight children. New York: Avon Press.

Hayden, T.L. (Producer) \& Marlowe, M. (Director). (2005). Relationship-driven

classroom management. $\{$ DVD $\}$. Boone, NC: Department of Reading Education and Special Education, Appalachian State University.

Hayden, T.L. \& Marlowe, M. (in press). Teaching children who are hard to reach:

Relationship-driven classroom practice. Thousand Oaks, CA: Corwin.

Hubble, M., Brandon, B., \& Miller, S. (1999). The heart and soul of change. Washington, DC: American Psychological Association.

Long, N.J. (2008). Breaking the trust barrier with troubled students. Reclaiming Children and Youth, 17 57-58.

Marlowe, M. (1999). Reaching reluctant students: Insights from Torey Hayden. Reclaiming Children and Youth, 7, 242-245, 254. 
Marlowe, M. (2006). Torey Hayden's teacher lore: A pedagogy of caring. Journal of Education for Teaching: International Research and Pedagogy, 32, 93-103.

Marlowe, M. (2011). The relationship-driven classroom: The stories of Torey Hayden. Reclaiming Children and Youth, 20, 24-29.

Morse, W.C. (2008). Connecting with kids in conflict: A life space legacy. Sioux Falls, SD: Reclaiming Children and Youth and Starr Commonwealth.

Resnick, M., Bearman, P., Blum, R., Bauman, K., Harris, K., Jones, R., et al. (1997). Protecting adolescents from harm: Findings from the national longitudinal study on adolescent health. Journal of the American Medical Association, 278, 823832.

Salavitz, M., \& Perry, B.D. (2010). Born for love. New York: Harper Collins.

Seita, J., Mitchell, M., \& Tobin, C. (1996). In whose best interest? Elizabethtown, PA: Continental Press.

Werner, E., \& Smith, R. (1989). Vulnerable but invincible: A longitudinal study of resilient children and youth. New York: Adams, Bannister, \& Cox.

Wilson, E. (1998). Consilience: The unity of knowledge. New York: Alfred A. Knopf.

Received: October 12th, 2011

Accepted: June 4th, 2012 